this gas is distinctly lower than over the land. This would appear to be most easily accounted for on the assumption that the pressure of carbon dioxide in the sea is constantly lower than that in the air, and that, therefore, the air must be steadily deriving supplies of the gas from some source, by means of which this difference of pressure is maintained. A. Harden.

\section{CONFERENCE OF PUBLIC SCHOOL SCIENCE MASTERS.}

THE annual meeting of the Public School Science Masters' Association was held for the second time at Westminster School on January 14, by kind permission of Dr. Gow, who had undertaken the duties of president and occupied the chair. A letter was read by the honorary secretary, Mr. W. A. Shenstone, from Sir Michael Foster explaining why he had not been able to act as president. The meeting then occupied itself with business matters, and Sir Oliver Lodge was unanimously elected president for the ensuing year.

In the short address with which Dr. Gow opened the conference, he expressed the opinion that every boy should be taught natural science, and this pronouncement, coming as it does from a classical headmaster, is of very great importance at the present moment, as Prof. Armstrong was not slow to point out. It was no doubt elicited by the subject of the first paper, namely, the importance of including both Latin and science in a scheme of general education. This was read by Mr. Douglas Berridge, of Malvern College. In the paper the necessity of a general education was discussed, and the report of the committee upon the education of army officers was taken as a guide. In this it is laid down that English, mathematics, one modern language, Latin, and science are essential to a sound general education; but what is very strange, the framers of the report proceed to propose that all future officers of our Army should be debarred from obtaining what was considered necessary by the proposal that Latin and science should be optional and alternative subjects. In addition to the injury which a one-sided education inflicts upon the individual, $\mathrm{Mr}$. Berridge pointed out a greater and more far-reaching danger to our nation as a whole. He urged that the present trend of education, as represented by London University (in its matriculation and school leaving examination), by Oxford and Cambridge (in their school leaving examinations), and by the Civil Service Commissioners and the Army entrance examinations, is sharply to divide Englishmen into two classes, the one trained on literary lines, leavened only by a modicum of mathematics, the other on scientific lines, leavened only by a smattering of French. Could it be, Mr. Berridge asked, to the advantage of any nation that its future rulers and organisers should thus be grouped into two opposing camps, of which, while they mutually despise one another, neither is able to understand the very method of reasoning adopted by the other? $\mathrm{Mr}$. Berridge was able to support his contention by figures, for on application to all our public schools he had found that for the Army and matriculation examinations 45.6 per cent. of the boys now learn Latin and 54.4 per cent. learn science.

The discussion showed that while the need of a literary as well as a scientific training was thoroughly recognised, many speakers did not agree with Mr. Berridge that Latin was the best means of acquiring the former. It is true that Father Cortie (Stonyhurst) found that the best classical boys were most successful in science, but Prof. Armstrong said that no honest attempt had ever been made in this country to afford a literary training through any other language, and though Latin had proved very efficient in a few instances, in the vast majority of cases it was not. He maintained, also, that Latin translation did not give style. Finally, Prof. Armstrong characterised the making of science alternative to Latin in Army examinations as illogical and preposterous. Dr. Gow said that he never regarded Latin as a literary training, but as a scientific one, and referred to his opening remarks, in which he had characterised the words as typical and exceptional genera and species, and parsing as scientific classification.

The paper dealing with recent proposals for school leaving certificates, by Mr. C. I. Gardiner, of Cheltenham, dealt with what has been done on the Continent, and afterwards with the regulations at present suggested to the Board of Education by its consultative committee. The paper welcomed, as did many of the speakers afterwards, what is not very happily expressed as State interference. Many of the Board of Education's proposals were characterised by $\mathrm{Mr}$. Gardiner as too vague, upon very good grounds. In the discussion, surprise was expressed that Mr. Gardiner had not mentioned what has been done recently in Ireland. It was recommended, also, that the Board of Education should get to know the schools before it suggested too much, and that its interference should be taken in small doses. Mr. W. A. Shenstone fancied he saw the edge of red tape in some of the proposals, while Father Cortie thought there was a danger that education might become stereotyped, so that special traits of certain schools would not be given free play. He hoped that inspectors with fads or insufficient knowledge would not interfere as they had done in elementary schools, and would not say, for instance, "your "labs' are not so good as those in the primary schools (which are built with the ratepayers' money), you must erect new ones."

The third paper dealt with the use and misuse of terms in science teaching. It was contributed by $\mathrm{Mr}$. T. L. Humberstone, of Toynbee Hall, who took exception to the loose way in which words, law, theory, hypothesis, and so on were used. $\mathrm{He}$ pointed out what the real meanings of the words were, and objected strongly to the idea that the experiments in practical mathematics "proved" the laws that they were intended to illustrate. Prof. Tilden agreed with $\mathrm{Mr}$. Humberstone in regard to the misuse of terms, and said that professional scientific men were just as much to blame as schoolmasters. He thought that if boys were taught a little logic before they left school many mistakes would be prevented. He was amazed at the statement incidentally made by $\mathrm{Mr}$. Humberstone as to there being too much laboratory work done in schools, and he pointed out that every discovery of the organic chemists was additional evidence in favour of the atomic theory which $\mathrm{Mr}$. Humberstone thought was tottering. Mr. Fletcher, of the Board of Education, said that there was a widespread misapprehension as to the place of practical work in geometry. It was not possible to prove anything by the experiments used, but it was most important to get approximations which could be idealised into conceptions. They were necessary to create a state of mind and to commend postulates to common sense. Mr. Sanderson thought that some of the practical work set to boys was superfluous, and might well be replaced by good experiments shown by the master. Mr. Humberstone, in answer to a question from Mr. Shenstone, said that he thought ten or twelve hours a week was longer than was required for laboratory work, and he further said, with regard to superfluous work, that when a boy had learned how to obtain one gas properly it was not necessary for him to produce all the others.

The last paper was by Mr. F. B. Stead, of Clifton, and was on the possibility of teaching scientific method to boys whose education is almost entirely literary, and who have no time for a regular course in chemistry and physics. It was suggested that older boys in the Vth form should be given some definite piece of work to be carried out in detail, in order that they might understand (I) the method of experiment and observation by which facts are ascertained; (2) the process of reasoning from particular instances to general laws; and (3) the use of explanatory theories and their verification.

Prof. Armstrong considered the paper to be one of very great value, and suggested that the term "experimental" should be used instead of "scientific," bearing in mind what Dr. Gow had said in connection with Latin as scientific training. He also asked what place there would be in the near future for boys who only had had a literary education.
Wilfred Mark WebB. 